\title{
Influence of growth hormone receptor exon 3 polymorphism on growth response in children with growth hormone deficiency
}

\author{
Seung Yang*, II Tae Hwang \\ From 8th APPES Biennial Scientific Meeting \\ Darwin, Australia. 29 October - 1 November 2014
}

\begin{abstract}
Aims
Pharmacogenetic effects of recombinant human growth hormone according to growth hormone receptor (GHR) exon 3 polymorphism (fl vs. d3) were controversial. We investigated growth hormone response in children with growth hormone deficiency (GHD).
\end{abstract}

\section{Methods}

Total 58 prepubertal children ( 31 boys and 27 girls) with GHD were enrolled in this study. Subjects were divided to 2 groups according polymorphism ( $\mathrm{fl} / \mathrm{fl}$, $\mathrm{n}=48 ; \mathrm{fl} / \mathrm{d} 3$ and $\mathrm{d} 3 / \mathrm{d} 3, \mathrm{n}=10$ ), and compared baseline phenotypes and the first year growth response to growth hormone treatment.

\section{Results}

The distribution of GHR exon 3 isoforms in children with GHD demonstrated that the frequency of $\mathrm{fl} / \mathrm{fl}$ $(82.8 \%)$ is higher than that in most of European studies. There was no significant difference in baseline height SDS between 2 groups. Height velocity during the first year of growth hormone replacement therapy tended to be higher in subjects who have $\mathrm{d} 3$ allele $(\mathrm{fl} / \mathrm{d} 3$ and $\mathrm{d} 3 / \mathrm{d} 3$ ), but there was no statistical difference according to genotype.

\section{Conclusion}

It seemed that $\mathrm{d} 3$ allele of GHR exon 3 had no impact on the baseline phenotype and growth hormone response in patients with GHD. Relationship between $\mathrm{GH}$ dose and IGF-1\% to help fully elucidate the value of IGF-1 testing in GH treatment.

Hallym University College of Medicine, Seoul, Republic of Korea
Published: 28 April 2015

doi:10.1186/1687-9856-2015-S1-P34

Cite this article as: Yang and Hwang: Influence of growth hormone receptor exon 3 polymorphism on growth response in children with growth hormone deficiency. International Journal of Pediatric

Endocrinology 2015 2015(Suppl 1):P34.
Submit your next manuscript to BioMed Central and take full advantage of:

- Convenient online submission

- Thorough peer review

- No space constraints or color figure charges

- Immediate publication on acceptance

- Inclusion in PubMed, CAS, Scopus and Google Scholar

- Research which is freely available for redistribution 